\title{
OBITUARY
}

\section{The death of an artist: Adrian Henri, 1932-2000}

\section{J R Ashton}

J Epidemiol Community Health 2002;56:72-75

The death has occurred in Liverpool of the artist, poet and public health practitioner manqué, Adrian Henri. This is a reflection on a collaboration that crossed C P Snow's two cultures,' which lasted almost 20 years and paid rich dividends for public health on Merseyside and way beyond.
M any of us "children of the sixties" grew up on the Beatles and the Liverpool poets. In the "Summer of Love" of 1968, Adrian Henri who, as one of the speakers said at his funeral, "loved love", spoke for all of us: ${ }^{2}$

\section{LOVE IS}

Love is feeling cold in the back of vans Love is a fan-club with only two fans Love is walking holding painstained hands

Love is

Love is fish and chips on winter nights Love is blankets full of strange delights Love is when you don't put out the light

Love is

Love is the presents in Christmas shops Love is when you're feeling top of the pops Love is what happens when the music stops

Love is

Love is white panties lying all forlorn Love is a pink nightdress still slightly warm Love is when you have to leave at dawn

Love is

Love is you and love is me Love is a prison and love is free Love's what's there when you're away from me

Love is.

It was in another lifetime that I personally began to connect to Adrian in the flesh. The opportunity came up to play an active part in designing and running health promotion activities at the 1984 International Garden Festival, which was intended to kick-start the regeneration of this once great city enduring hard times. Adrian's book, Total art-environments, happenings and performance, was the obvious text, and it was about this time that Adrian and my paths converged. A five month long garden festival, with four and a half million visitors, presented a unique opportunity to use the whole environment to explore health issues in a holistic way.
Extensive discussions took place with the Festival designers about how the whole site could be inseminated with a health perspective. ${ }^{4}$ One discussion, for example, was about the tides of the adjacent River Mersey and the observatory opposite; how an interpretation of this might give people insight into a large scale human habitat called Liverpool, its origins and raison d'être. Another discussion centred on using the Festival to explore the gulf between town and country, with its implicit loss of an understanding of the cycles of nature and the seasons that can afflict the urban poor, except for the impact of the cold in winter. Thinking was much influenced by a "happening" around the corner from Adrian's house in the centre of Liverpool, when a derelict site adjacent to the Cracke public house was turned into the seaside for the day for local children, made possible by the gift of truckloads of sand from a local builder and complete with sandcastle competitions, ice creams and games.

The Health presence at the Garden Festival, though less ambitious than originally conceived, did manage to penetrate all quarters of the site. A static, large scale health fair (the first such to provide mass fitness testing and personal lifestyle advice) was complemented by static and dynamic displays, especially in the area given over to small vegetable gardens. Health orientated activities, such as aerobic dance, yoga, sports and public participation, music and poetry completed the picture.

In 1986, the Copenhagen office of the World Health Organisation began the Healthy City initiative, and I was asked to be the first coordinator. My collaboration with Adrian took off at this point, and eventually Adrian made contributions to public health through a wide range of media and activities. ${ }^{56}$

At the first Healthy Cities conference, held in Lisbon in 1986, I presented a paper-“"Esmedune 2000 " - which sought to draw together a strategic vision for a future, regenerated Liverpool based on a coalescence of community initiatives and more formal, large scale public works projects. Adrian responded immediately by writing his poem entitled City 2000.?

\section{CITY 2000}

In this city

filled with the sound of alarm-bells

police-sirens howl

like animals mating.

Vagrants huddle together

in cardboard cities;

in a damp bed-sit

a girl dreams visions of Patmos 
Cool white spaces

The dusk gleam of an ikon

The night

written in dripping white

on a railway wall

'Swarming city, city full of dreams'

In this city

the sound of the bulldozer is banished from the land

Swingeing custodial sentences imposed

on anyone designing a building finished in shuttered concrete

Car parks burst into flower

narcissi, blue-flags, lillies-of-the-valley

pushing up through the tarmac,

the streets heaped with yellow marigolds

All planning decisions are referred to

The postman Ferdinand Cheval

Charles Rennie Mackintosh

and

Antoni Gaudi

(all speaking through a medium)

This city

no longer an embarrassment

The too-much-loved-mother

at the school speech day

lipstick blurred

smelling of gin-and-lime

As the sun rises over this city

Your morning face on the pillow

Through strands of dark brown hair

The river lying back open to the day

the lace curtains of terrace houses

Sing like school children

This city

is your mother

and your lover

She is your first thought

and your last

She is your future and your past

Subsequently, despite a very full career as a mainstream artist (both fine and performance) and poet, Adrian Henri became ubiquitous in public health and work for Healthy Cities. Adrian regularly taught on the Liverpool Masters in Public Health course, his mural of Esmedune (fig 1) adorns the wall of a seminar room in the University of Liverpool's Public Health Department, and Adrian contributed the video commentary for the highly successful International Healthy Cities conference held in Liverpool in $1988 .{ }^{7}$

In 1990, Spanish Healthy Cities links led to a British Council fellowship for Adrian to go to Valencia in Spain to explore the health dimensions of the famous Fallas festival with Carlos Alvarez and Concha Colomer-an extreme happening dating back to the middle ages involving community constructed installations, incendiary on a large scale. "Why is a British painter and poet (and occasional singler/songwriter and playwright) visiting Fallas under the auspices of Healthy Cities 2000?" Adrian asked, before answering his own question most convincingly.

In 1997, Liverpool celebrated 150 years of public health, having been the first British city to appoint a Medical Officer of Health (William Henry Duncan, in 1847) with whom Adrian shared a name-albeit spelled differently. ${ }^{8}$ Adrian became the Public Health Artist in Residence for the year, and set things off with his Ode to Dr Duncan.'

\section{ODE TO DR DUNCAN}

"... this Duncan

Hath borne his faculties so meek, hath been

So clear in his great efforts, that his virtues

Will plead like angels ..."

Shakespeare, Macbeth

As I was a-walking down Paradise Street

a figure in black I happened to meet

a smile on his face instead of a frown

a ghost walks the streets of Liverpool Town

He presses his nose to the window

to see rows of whirling glass eyes

in the brightlit launderette

like a child at Christmas.

Choking cellars of Cazneau Street

Dark courts of Duke Street...

Turning on impulse to home, he walks down Seel Street;

dazed by the neon lure of nightclubs,

he does not notice the familiar figures

huddled on the steps of the Mission of Charity.

Cheapside and Lace Street

Blind alleyways of Milton Street ... .

He nods approvingly at grids and litterbins, tuts to himself as he notes cracked pavements, burst-open black bags, polystyrene food-trays, drifts of chip-papers, abandonded copies of THE BIG ISSUE.

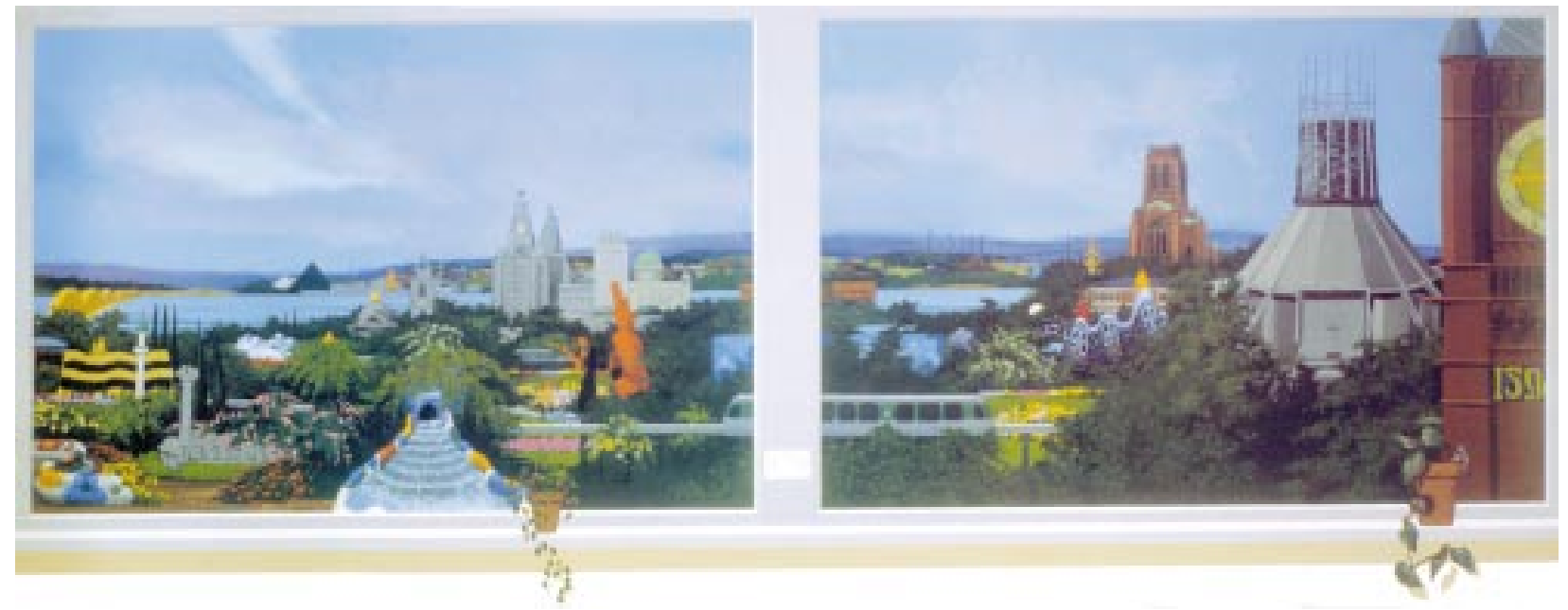

Figure 1 Esmedune. 


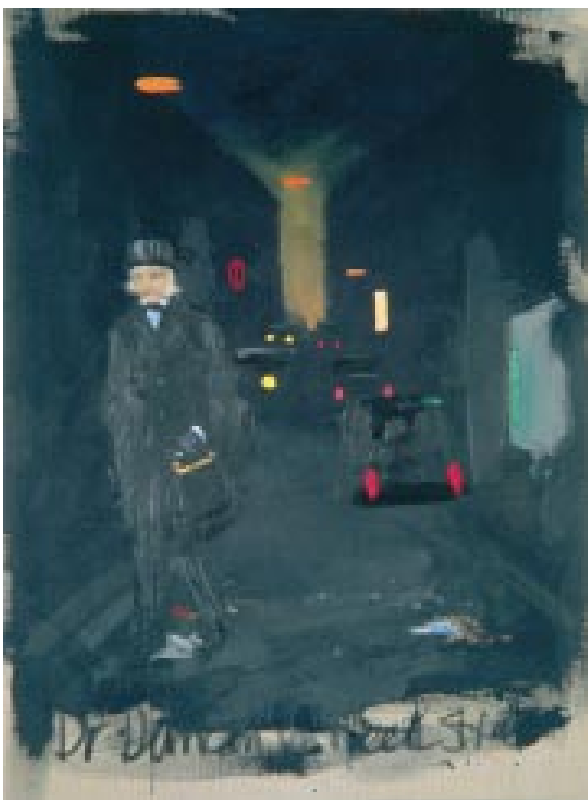

Figure 2 Dr Duncan in Seel Street.

Effluent-filled entries of Edge Hill Dark empire of the Necropolis...

Tracing his daily route from Rodney Street to work in Upper Parliament Street

he sees the girls' white familiar faces at the corner, wonders only at the shortness of their skirts.

Guiding Star, Garrick, Clare Wheeler

Ghost plague-ships haunt the Mersey mist ...

He smiles at the curtained glow of tidy houses where typhoid and cholera once stalked the street, does not see the bleak estates where skeletons dance to the electric beat of poverty.

As I was a-walking down Paradise Street a figure in black I happened to meet a smile on his face instead of a frown a ghost walks the streets of Liverpool Town
Joined by the crimolined shade of Kitty Wilkinson, he pauses politely to offer an arm.

Beyond the traffic lights their figures fade

in the Grimshaw mist of the Old Dock Road.

Collaborating with Maggi Morris and The Duncan Society and, most importantly, his partner Catherine Marcangeli, Adrian went on to produce and facilitate an abundance of creative riches culminating in the "Dr Duncan Art Show", which was wrapped around an exhibition in one of the city's museums entitled "A Healthy Place to Live" that explained many themes of 150 years of public health in Liverpool. The Dr Duncan Art Show itself brought together the work of 15 Merseyside painters and sculptors, hand picked by Adrian and responding to his challenge to represent what public health meant to them through their own chosen medium. Adrian's own contribution was to be one of his last large canvasses-Dr Duncan in Seel Street (fig 2), a representation of the public health pioneer in a contemporary streetscape of his old Liverpool stamping ground.

And there was much more to this most generous and humanistic man. Adrian was on hand to respond through the written word and canvass to the Hillsborough football disaster of 1988, contributing to understanding and to the healing process (fig 3).

\section{THE BELL}

The bell

tolled all afternoon

we did not send to ask

for whom.

It told of flowers

heaped in a goalmouth,

red and blue scarves

heaped together at an altar;

it told of

eyes like TV screens

haunted by last night's images

tears dried by the April wind.

As the flags at half-mast

stirred overhead

the deep bell

still tolled in our heads

long after the light had gone.

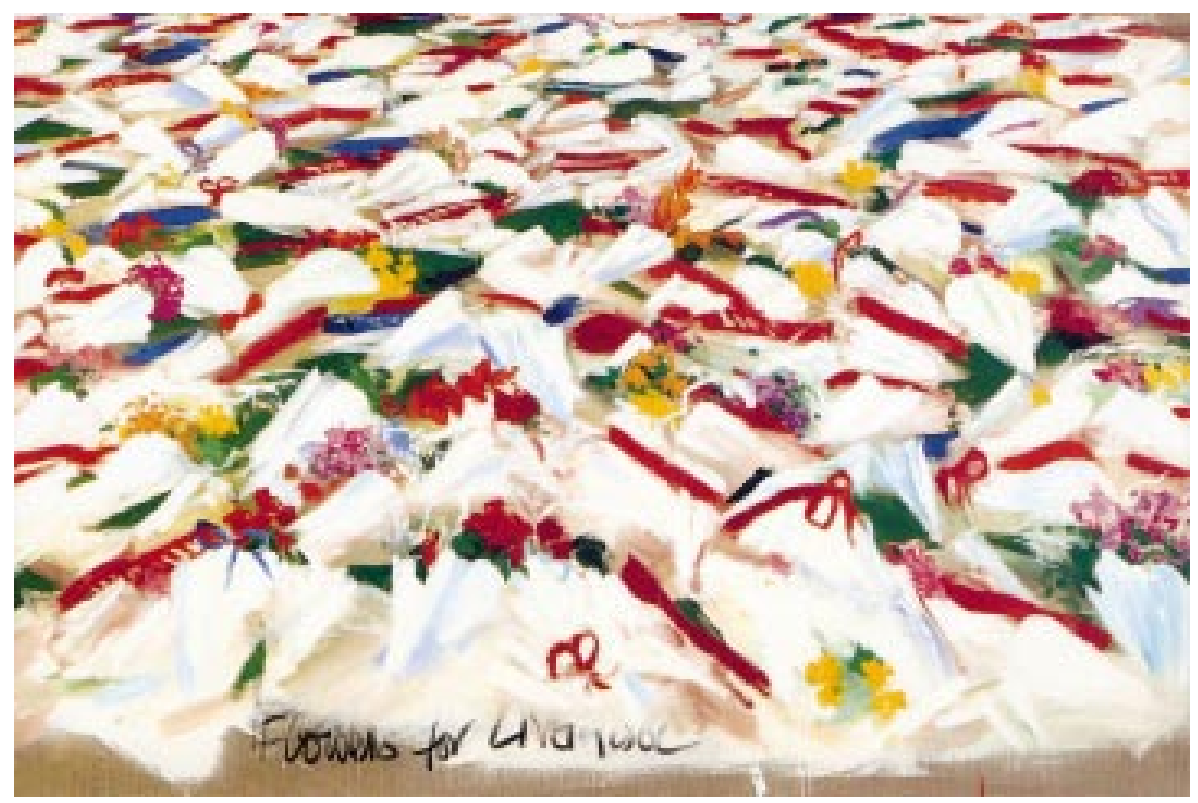

Figure 3 Flowers for Liverpool. 
And in 1997, Adrian Henri's version of the "Hippocratic Oath" appeared in the Observer newspaper: ${ }^{10}$

"For a new oath you could apply

for joint finance from PFI*

or have a private ode from BUPA ${ }^{\dagger}$

Super. Of course

the government regrets, but

'without fee or covenant',

'for benefit of my patients'

and all that ancient stuff

won't do. Frankly, we're

advising downsizing. Perhaps

a Hippocratic haiku,

seventeen syllables or less;

you won't get more

on the NHS."

Adrian felt that there had been a public assumption that contemporary artists were self indulgent and living in ivory towers. He completely dispelled any perception that this was how it had to be and in his holistic understanding of health he expressed an understanding that was at the very heart of the World Health Organisation's "Health for All" vision.

Sadly, and devastatingly, Adrian suffered a massive stroke at the beginning of 1999, and despite the wonderful devotion and therapy provided by Catherine, a marvellous demonstration of love in action, complete recovery was tantalisingly out of reach. A retrospective exhibition of Adrian's work at the Liverpool Walker Art Gallery in spring 2000 proved to be a tour de force of the range and power of this man's contribution to Merseyside's culture and beyond. ${ }^{11}$ And in those final months,

* Private Finance Initiative. ${ }^{\dagger}$ British United Provident Association. Formed in 1947, BUPA is now a global private health insurance company. there were some poignant final contributions from the palate of faltering recovery.

At the very moment of universal civic acclaim-honorary degrees from the local university, freedom of the City of Liverpool-Adrian succumbed on 20 December 2000. He had, of course, been recognised by the public health community by the award of the prestigious Duncan Medal for his contributions to public health.

\section{ACKNOWLEDGEMENTS}

I am deeply indebted to Catherine Marcangeli for permission to reproduce Adrian's writings and paintings.

\section{REFERENCES}

1 Snow CP. Two cultures and the scientific revolution. Cambridge, UK: Cambridge University Press, 1959

2 Henri A, McGough R, Patten B. The Mersey sound. Penguin Modern Poets series, number 10. Harmondsworth, UK: Penguin, 1974.

3 Henri A. Total art. Environments, happenings and performance. London: Thames and Hudson, 1974.

4 Ashton J, Seymour H. The new public health. Milton Keynes, UK: Open University Press, 1988

5 Ashton J, ed. Healthy cities. Milton Keynes, UK: Open University Press, 1991.

6 Ashton J, Morris M. The new public health and the arts: report of a partnership in action. In: Senior $\mathrm{P}$, ed. Culture, health and the arts-an anthology. Report of the culture, health and the arts symposium, held at Manchester Metropolitan University, April 1999. Manchester:

Manchester Metropolitan University, 2000. ISBN 1-900-75613-7.

7 Ashton J, Knight L, eds. Proceedings of the first United Kingdom Healthy Cities Conference, Liverpool, 28-30 March 1988. Liverpool, UK: Department of Public Health, University of Liverpool, 1990. ISBN 0-9512434-2-X

8 Frazer WM. William Henry Duncan. London: Hamish Hamilton, 1947.

9 Henri A. A dream of doctor Duncan. In: Morris M, Sheard S, eds. Liverpool 1997-Celebrating 150 years of public fealth. Liverpool: The Duncan Society, c/o University of Liverpool. (duncan-society@ liverpool.ac.uk)

10 Henri A. Dear Dr Hippocrates. The Observer, 1997; 6 July:3.

11 Henri A. Paintings 1953-1998. Liverpool: National Museums and Galleries on Merseyside, 1999. ISBN 1-902700-07-4. 